\title{
The Determinants of Users' Behaviour on Social Media: The Role of Religion and Personal Values
}

\author{
Elistina Abu Bakar, Nur Jannah Draman \& Aznan Zuhid Saidin
}

To Link this Article: http://dx.doi.org/10.6007/IJARBSS/v11-i12/11924 DOI:10.6007/IJARBSS/v11-i12/11924

Received: 06 October 2021, Revised: 07 November 2021, Accepted: 27 November 2021

Published Online: 17 December 2021

In-Text Citation: (Bakar et al., 2021)

To Cite this Article: Bakar, E. A., Draman, N. J., \& Saidin, A. Z. (2021). The Determinants of Users' Behaviour on Social Media: The Role of Religion and Personal Values. International Journal of Academic Research in Business and Social Sciences, 11(12), 2005-2018.

\section{Copyright: (c) 2021 The Author(s)}

Published by Human Resource Management Academic Research Society (www.hrmars.com)

This article is published under the Creative Commons Attribution (CC BY 4.0) license. Anyone may reproduce, distribute, translate and create derivative works of this article (for both commercial and non0-commercial purposes), subject to full attribution to the original publication and authors. The full terms of this license may be seen at: http://creativecommons.org/licences/by/4.0/legalcode

Vol. 11, No. 12, 2021, Pg. 2005- 2018

Full Terms \& Conditions of access and use can be found at http://hrmars.com/index.php/pages/detail/publication-ethics 


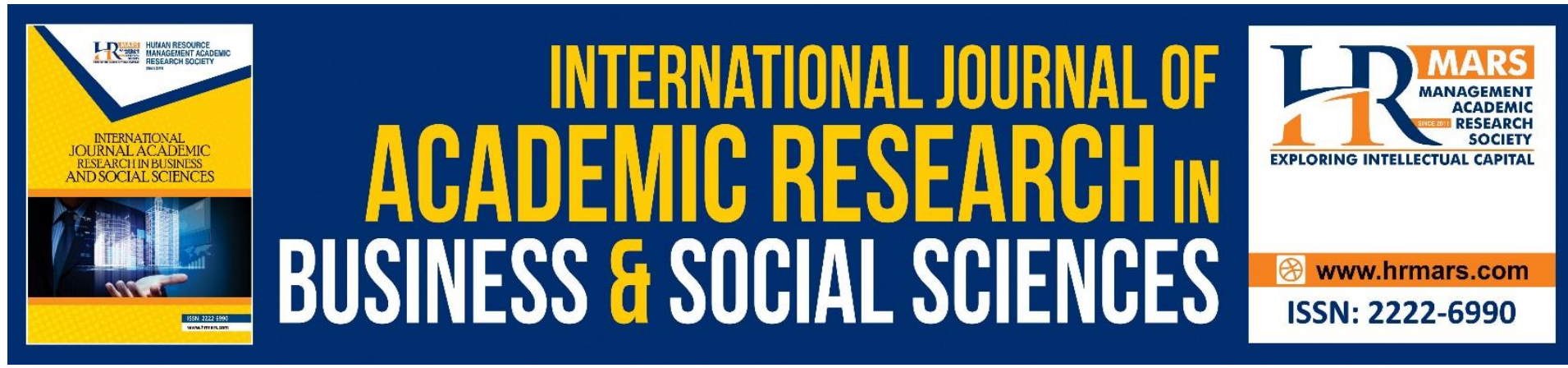

\title{
The Determinants of Users' Behaviour on Social Media: The Role of Religion and Personal Values
}

\section{Elistina Abu Bakar ${ }^{1,2}$, Nur Jannah Draman ${ }^{1}$ \& Aznan Zuhid Saidin ${ }^{3}$}

${ }^{1}$ Department of Resource Management \& Consumer Studies, Faculty of Human Ecology, Universiti Putra Malaysia, 43400 Serdang, Selangor, ${ }^{2}$ Halal Products Research Institute, Universiti Putra Malaysia, ${ }^{3}$ Department of Information Systems, International Islamic University Malaysia.

Email: elistina@upm.edu.my, aznanz@iium.edu.my

\begin{abstract}
The objective of this paper is to examine the role of religion and personal values as the determinants of users' behaviour on social media. The role of religion refers to the level of religiosity and the perceptions towards Maqasid al-Shariah principles. Age factor regarding the behaviour was also explored. This study was an exploratory study which only involved one hundred and sixty Muslim users of social media in Kuala Terengganu who were chosen through random sampling. The Social Cognitive Theory was used to explain the users' behaviour. The analysis shows that the level of religiosity, the perceptions towards Maqasid al-Shariah and personal values explain $33.6 \%$ variance in the behaviour of the respondents while using social media and the level of religiosity becomes the main determinant. This finding gives a significant implication to government, consumer movements and users so that the pillars of religion should be embedded in all education policies and programs to inculcate good behaviour among users of social media.
\end{abstract}

Keywords: Behaviour, Social Media, Religion, Personal Values, Maqasid Al-Shariah

\section{Introduction}

Nowadays, mobile platforms or web can allow users to connect with their peers and friends within a virtual network. Common forms of social media include Facebook, Instagram, Twitter or Linkedln that will enable the users to create, share or exchange various forms of digital content including photos or videos. Researches have demonstrated many benefits to users who have routinely engaged on social media such as they can enhance their social connection and improve their communication skills. It will also assist users to increase their well-being especially with the introduction of e-commerce, e-learning and e-government (Ahmed et al., 2019).

On the other hand, excitement and anticipation brought by this new media may lead to many problems especially if the users are illiterate of this technology and its negative impacts. Among the problems commonly faced by users are the issues of privacy, security, inaccurate 
information, technology addiction and many others. According to the statistics released by Cyber Security Malaysia in 2021, the number of cyber security incidents were about 6615 incidents with fraud reported as the highest number (4729 incidents) followed by intrusion (1003 incidents). These numbers are alarming and this shows that crimes happened rampantly online and pose danger to social media users.

This new medium of communication will also change the users' values and lifestyle (Colicev et al., 2018). There are many efforts to bring religion into the world of the Internet which is known as 'online religion' (Ashaari et al., 2017). Muslim societies use the social media to search information related to Islamic religious issues such as Islamic law, current issues in Islam and the Muslim world, the history or the Prophet, seek answers for religious' curiosity and find interpretation of Islamic law and Al-Qur'an (Faradillah, 2015). In addition, the social media is also used as a resource for learning more about Islam such as seeking information about religious beliefs, practices and doing da'wah (Al-Mashrafi, 2013). The negative impact is Islam in cyberspace allows many parties to act as mujtahid and this will trigger deviance in Islamic teachings (Hamid, 2016). The dissemination of false hadith and unauthentic opinions will bring slander to the Muslim teachings and the religion itself.

Islam also provides for certain ethics in communicating and interacting irrespective whether it is conducted in the real world or on social media. The unanimity of this new media should not be an excuse for the users to behave negatively since Islam emphasizes on the concept of al-Ihsan (Hamid, 2016). Therefore, it is hoped that religion plays an important role in shaping users' way of thinking as well as their conducts. The role of religion in this paper refers to the level of religiosity and also the perceptions towards the principles of Maqasid al-Shariah. User's personal values are also important to shape their behaviour. Therefore, this article will explore the relationship between the level of religiosity, personal values and the perceptions towards the principle of Maqasid al-Shariah and the behaviour of Muslim users of social media. Age factor is also examined to determine its influence on the behaviour.

\section{Literature Review}

The Theory of Cognitive Learning by Piaget (1964) which was later developed by Bandura (1978) was known as the Social Cognitive Theory. It explained that cognitive must involve personal factors, environmental factors and behaviour whereas both personal and environmental factors will influence one's behaviour. Individual factors include the biological characteristics of a person such as belief, self-perception, goals, and intentions in shaping their behaviour. According to Bower (1978) and Bandura (2009), what one thinks, believes and feels determine how they behave. Cognitive and affective domains under the individual factors had been proven to affect one's behaviour. Thus, according to this theory, religious belief and values were individual factors that would determine how the individual behaves (McQuail, 1994).

Social media is a powerful medium of communication that can shape changes in the thinking, attitude and behaviour of users who use them (Ping et al., 2019). However, these social media platforms need to be utilized in a positive way to facilitate interaction with others (Cheung et al., 2021). The literature on ethical behaviour emphasized that the users must recognize the unethical conduct and the factors to resist such behaviour were determined by family influences, religious values and personal experiences (Khazanch,1995; Abutaleb et al., 2021). 
The internet has become easily accessible and the use of social media as a popular mode of communication was well accepted by users. However, there was also the increase of unethical use of the social media among users (Siddiqui \& Singh, 2016). As such, it is important to study the behaviour of social media users by determining the predictive factors that can shape those behaviour.

\section{Personal Values}

According to the affective domains under the Social Cognitive Theory, the acceptance of the individuals towards any behaviour depends on the personal values they possess (Schwartz, 1994). Strong values determine the extent to which they will behave. According to Nurazlina et al., (2015), personal values refer to the belief of an individual which later becomes the principles that guide the behaviour of individuals. Affective factors such as personal values held by social groups are often discussed but rarely studied empirically (Homer \& Kahle, 1988).

High literacy accompanied by values is the essence to teach individuals to appreciate any issue and problem (Nurazlina et al., 2015). It is an important principle that guides an individual what is considered to be right and wrong. Therefore, many scholars are in the opinion that consumer education is the cornerstone of the individuals to get the best value appreciation (McGregor, 2000).

Nevertheless, the challenge in the new world of technology is the information which is easily obtained can penetrate the culture and value system of the society (Imran et al., 2021). For example, life that relies heavily on technology creates individualistic attitudes and departs from value of self-belonging in the community. It also creates a phenomenon in which people are struggling to stand out in cyberspace. The importance of popularity becomes a value that they possess and therefore they will share pictures and keep updating their status without considering whether their behaviour will lead to negative consequences (Ashaari at al., 2017). It was consistent with a study conducted by Shompa et al (2019) among university students where the findings revealed that users' personal values can guide them to behave properly in social media and subsequently can protect the information, privacy, security and dignity while they are in cyberspace.

\section{Religiosity}

The significance of religion to human beings in daily life has made it an important area of inquiry to many researchers. The problem in this new technology era is people are no longer guided by religious teachings. Consequently, various issues happened on social media which affect the sanctity of religion (Ashaari et al., 2017). For example, the use of expression of obscenity (offensive language) on social media showed immoral behaviour (Justin et al., 2019). As a Muslim, it is important to have a strong holding of religious principles because it can prevent them from being influenced by unhealthy social behaviour. Religion can give a profound impression on the feeling of the individuals and the cultivation of faith or belief in heart and soul is the most appropriate solution to create the elements of goodness in individuals and can heal social ill happened due to social media (Fazli et al., 2015).

Al-Zeera (2001) discussed the unifying role of tawhid, and its influence on the social and interpersonal aspects of man's behaviour. Apart from that, adopting and practicing tawhid 
not only integrates individual's personality but it can underlie community relationship in which people with differences will be able to unite. This pillar of religion should be upheld even the technology has evolved from face-to-face relationship to virtual relationship.

One of the social media features is anonymity. This will create a perception that anyone can do anything because no one knows. However, if the person upholds the principle of ihsan, he will not behave badly because he believes that the God knows all his wrongdoings. This will deter the individual from doing something negatively (Abu Zahrah, 1997). Thus, lack of religiosity had significant relationships with immoral behaviour of individual. It had been proven empirically among young persons in Bangladesh that religiosity correlate negatively with the sharing of unverified information (Najmul et al., 2020). As such, it is interesting to determine the relationship between the religiosity and the behaviour of users while using the social media in Malaysia, particularly in Kuala Terengganu.

\section{Maqasid al-Shariah}

Maqasid al-Shariah plays an important role in human behaviour. According to Imam Al Ghazali (Abu Zahrah, 1997), the ultimate principle of Maqasid al-Shariah lies in the preservation of religion, life, dignity, intellect and property. Considering the importance of these five main objectives of shariah, the Maqasid al-Shariah principles can be the basis to regulate social media use and subsequently can protect the sanctity of religion. However, there was not much literature on the perception towards Maqasid al-Shariah among Muslim that guide their behaviour that had been tested empirically though there were abundant literature that had discussed these principles conceptually. Shompa et al., (2019) had studied the perception towards Maqasid al-Shariah principles among university students and found that there these perceptions can shape their behaviour while using the social media.

This is because these perceptions should be a guiding principle for doing good activities and refrain from doing harmful activities on social media. For example, the users should not create, share and search content on social media which causes damage either to religion, life, dignity, intellect and property of the other social media community. At the same time, the users should use the social media to encourage good activities that lead to fulfill the higher objective of preserving al-din such as utilizes it as a medium of doing $d a^{\prime} w a h$ (Ashaari et al., 2017).

\section{Age factor}

According to a survey done in America, teens are more likely to share self-created content online like photos, videos, artwork or stories compared to adults (Pitts \& Woodside, 1983). However, there is a gradual tendency for the adults to do the same (Hruska \& Petra, 2020). The same findings also derived from a study by Jeretta et al., (2020). where they found that there was a difference by age in the behaviour on social media. They found that social media use was particularly important among the young adult cohort. This is because young people grew up with these digital options compared to older people who had to learn how to use them (Hopkins \& Chris, 2021). Therefore, differences may emerge across generations.

In Malaysia, many studies related to social media use were done among adolescents. Teenagers spent at least one day using Facebook and school children like to surf the internet especially social media (Hassan \& Rashid, 2012). Many of them have also become addicted 
and known as cybermania. A study was done among youth, aged between 17-40 years old and was found that they used the social media more for sharing negatively-oriented information compared to the positively-oriented information (Saodah et al., 2012). However, there is no study done in Malaysia determining the influence of age difference on the behaviour of users while using social media.

Therefore, based on the above analysis of the literature, the following hypothesis was formulated:

$\mathrm{H}_{0} 1$ : Personal values, religiosity, the perceptions towards Maqasid al-shariah and age are not the predictors of user's behaviour in social media.

\section{Methodology}

This study was conducted in Kuala Terengganu and the population of this study was made up of only Muslim consumers. It was a quantitative study which was conducted through a survey among 160 Muslim users. Four residential areas which are located in Kuala Terengganu were randomly selected and 40 households were systematically chosen to represent each residential area based on their house number. To get the sampling interval of that area, the population size was divided by the desired sample size. However, only one respondent was chosen to represent one household based on the most active users of social media in that household. As such, a total of 160 respondents had participated in this study. Since it is an exploratory study, the sample size is still sufficient but the limitation is the findings need to be read in more caution due to small sample size (Dillman, 2000).

The questionnaire was developed to measure the factors affecting users' social media behaviour. The questions in Part A were to collect respondents' socio-demographic related information and the types of social media they routinely used for the past 12 months. The respondents could tick more than one option for the types of social media that they commonly engaged. Part B was the questions regarding the three determinants which were the level of religiosity (22 items), the personal values ( 9 items) and the perceptions towards Maqasid al-Shariah concept ( 9 items). The items for personal values were adopted from the List of Value (LOV) by Kahle and Kennedy (1988). The respondents were expected to rate the importance of each value ranging from 1 'which is very unimportant' to 9 which is 'very important'. The measurement for religiosity referred to the extent the respondents perceived faith as important to guide their conducts as well as their Islamic worldview which have been adopted from the Muslim Religiosity and Personality Inventory (Institute for Community and Peace Studies, 2006). The score ranging from " 1 " = strongly disagree to 5 "strongly agree". On the other hand, the perceptions towards Maqasid al-Shariah principles referred to the extent the respondents perceived five Shariah essentials which are to preserve religion, intellect, life, wealth and dignity. The items were adopted from Shompa et al (2019) and measured by using 5-point scale based on their agreement to the given statement.

The items to measure social media behaviour were in Part $C$ where they were adopted from the ten commandments of computer ethics. This is because using computer ethics as a parameter can determine unethical computer behaviour (Computer Ethics Institute, 1992) and the 5-point scale was also adopted to anchor each item. The reliability test showed coefficient alphas of 0.903 for personal values, 0.870 for level of religiosity, 0.724 for Maqasid al-Shariah and 0.715 for behaviour. As such, the measurements for all variables were reliable. 
The data was analysed by using the Statistical Package for Social Science version 23 (SPSS). Multiple regression analysis was conducted to determine the predictive factors of users' behaviour in social media.

\section{Results and Discussion}

\section{Background of the Respondents}

The background characteristics of the respondents were presented in Table 1. The respondents comprised of $60.0 \%$ female and $40.0 \%$ male out of 160 respondents. About $15.6 \%$ of the respondents were below 25 year old while nearly half of the respondents were in the age of 25 to 35 (49.5\%) and very few were above 56 (2.3\%). The mean age was 37 years old. As far as their marital status were concerned, $61.7 \%$ of them were married while $28.3 \%$ were single. Regarding their qualification, about half of the respondents (49.2\%) hold a degree, $27.5 \%$ of the respondents hold diploma and $17.5 \%$ acquired at least SPM qualification.

Most of the respondents had used WhatsApp (90.6\%), Facebook (44.3\%) and Twitter (43.1\%) as the social media platforms. This finding was also consistent with other study which had also indicated these three types of platforms as the common types of social media platform used in Malaysia (Shompa et al., 2019). 
Table 1: Background of the Respondents

\begin{tabular}{|c|c|c|}
\hline $\begin{array}{l}\text { Socio-demographic } \\
\text { characteristics }\end{array}$ & $n=160$ & $\begin{array}{l}\text { Percentage } \\
(\%)\end{array}$ \\
\hline \multicolumn{3}{|l|}{ Gender } \\
\hline Male & 64 & 40.0 \\
\hline Female & 96 & 60.0 \\
\hline \multicolumn{3}{|l|}{ Age } \\
\hline Below 25 & 25 & 15.6 \\
\hline $26-35$ & 80 & 49.5 \\
\hline $36-45$ & 29 & 18.4 \\
\hline $46-55$ & 22 & 13.7 \\
\hline Above 56 & 4 & 2.3 \\
\hline \multicolumn{3}{|l|}{ Mean age was 37 years old } \\
\hline \multicolumn{3}{|l|}{ Status } \\
\hline Single & 45 & 28.3 \\
\hline Married & 99 & 61.7 \\
\hline Widow/er & 16 & 10.0 \\
\hline \multicolumn{3}{|l|}{ Level of education } \\
\hline SRP/PMR/PT3 & 2 & 1.6 \\
\hline SPM/MCE & 28 & 17.5 \\
\hline STPM/Certificate/Diploma & 44 & 27.5 \\
\hline Degree & 79 & 49.2 \\
\hline Master/PHD & 7 & 4.2 \\
\hline \multirow{2}{*}{\multicolumn{3}{|c|}{$\begin{array}{l}\text { Types of social media use } \\
\text { (Can choose more than } \\
\text { one) }\end{array}$}} \\
\hline $\begin{array}{l}\text { one) } \\
\text { Facebook }\end{array}$ & & \\
\hline Facedook & 145 & 90.6 \\
\hline WhatsApp & 53 & 33.1 \\
\hline Instagram & 69 & 43.1 \\
\hline $\begin{array}{l}\text { Twitter } \\
\text { Others }\end{array}$ & 9 & 5.6 \\
\hline
\end{tabular}

\section{Personal Values, Religiosity and Maqasid al-Shariah}

Table 2 shows the descriptive analysis of all the studied determinants which are personal values, the level of religiosity and the Maqasid al-Shariah principles. The 9-point scale is used to measure value whereas for the other two variables the 5-point scale was utilised.

Table 2: Personal Values, Religiosity and Maqasid-al Shariah

\begin{tabular}{|c|c|c|c|}
\hline Determinants & & Mean & SD \\
\hline Personal values & & 7.73 & 1.46 \\
\hline Religiosity & & 4.69 & 0.57 \\
\hline Maqasid al-Shariah & 4.71 & 0.53 & \\
\hline
\end{tabular}

The total mean score for personal values was 7.73 out of 9 scales which shows that the respondents believed all the nine values were important. The listed nine values were sense of belonging, excitement, warm relationship, fun and enjoyment, self-respect, well respected, 
sense of accomplishment, security and self-fulfilment. The high scores for the items also indicated that the interaction in virtual world is exciting, lots of fun, establish warm relationship and ultimately can self-fulfil one's need.

The overall mean score for the level of religiosity was 4.69 out of 5 scale which was considered high. It means that the respondents perceived faith as important to guide their conducts as well as they hold a strong belief in their religion. On top of that, the respondents' views regarding the Maqasid al-Shariah principes were also explored. The five essentials under Maqasid al-Shariah which were to preserve religion, intellect, life, wealth and dignity were explored. The overall mean score was 4.71 out of 5 scale and it showed positive perceptions towards these principles. This descriptive analysis demonstrates that the respondents hold high regard on value $(M=7.73, S D=1.34)$, high level of religiosity $(M=4.69$, $\mathrm{SD}=0.57)$ and have positive perceptions toward the Maqasid al-Shariah principes $(\mathrm{M}=4.71$, $\mathrm{SD}=0.53)$.

The items to measure social media behaviour were adopted from the ten commandments of computer ethics. Ten unethical behaviours while using social media were listed to measure the behaviour. The results showed that the overall mean score was 1.64 out of 5 scale and since the listed items were negative behaviour, the lower mean score indicated positive behaviour. Table 3 illustrates the mean score for the social media behaviour.

Table 3: Social Media Behaviour

\begin{tabular}{|c|c|c|}
\hline Behaviour & Mean & Sd \\
\hline 1. Use social media to harm others. & 1.34 & 0.72 \\
\hline 2. Interfere with other people's social media account. & 1.29 & 0.65 \\
\hline $\begin{array}{l}\text { 3. Snoop around into other people's social media } \\
\text { account. }\end{array}$ & 1.53 & 0.87 \\
\hline 4. Use to steal information. & 1.42 & 0.61 \\
\hline 5. Use a computer to bear false witness. & 1.31 & 0.73 \\
\hline 6. Copy a proprietary software. & 1.84 & 1.09 \\
\hline 7. Use other people's social media resources. & 1.49 & 0.83 \\
\hline 8. Appropriate other people's information. & 1.62 & 0.85 \\
\hline $\begin{array}{l}\text { 9. Share something without thinking social } \\
\text { consequences. }\end{array}$ & 2.45 & 1.19 \\
\hline 10. Do not show respect for fellow users of social media. & 2.15 & 1.05 \\
\hline Total mean & 1.64 & 0.86 \\
\hline
\end{tabular}

The highest mean score of 2.42 was for item 9 which is "I share something without thinking about the social consequences" and item 10 which was "I do not show respect for fellow users of social media." While the lowest mean score is item no 5, "I use a computer to bear false witness" which was 2.15. For the questions in this section, the higher the mean score, the more negative the behaviour was. Therefore, it seems that the users are less sensitive about social consequences of their behaviour even though as the whole their behaviour was positive. The findings were also consistent with Siddiqui \& Singh (2016) where they found the similar negative behaviour of users and its impact on society and youngsters. 


\section{Determinants of User's Social Media Behaviour}

Table 4 shows the result of multiple regression analysis in order to determine whether age, the personal values, the level of religiosity and Maqasid al-Shariah principles were the predictive factors of users' behaviour while using social media. The results showed that all factors, except age, could explain 33.6\% variance in the behaviour of respondents while using social media. The full model was highly significant $(F=19.55$, sig. $=0.000)$ since the $p$-value was less than 0.001 .

Table 4: Multiple Regression

\begin{tabular}{lcccl}
\hline Variable & $\mathbf{B}$ & $\boldsymbol{\beta}$ & \multicolumn{1}{c}{$\mathbf{T}$} & Significant \\
\hline Age & -.067 & -.125 & 1.704 & 0.089 \\
Personal value & -.089 & -.156 & 2.002 & $0.048^{*}$ \\
Religiosity & -.613 & -.453 & 5.136 & $0.000^{* *}$ \\
Maqasid al-shariah & -.253 & -.215 & 2.594 & $0.000^{* *}$ \\
\hline
\end{tabular}

$\mathrm{R}^{2}=.0 .336$, Adjusted $\mathrm{R}^{2}=.319, \mathrm{~F}=19.549$, Sig. $\mathrm{F}=0.00$

$* p \leq 0.05, * * p \leq 0.01$

From the analysis, the personal values, the level of religiosity and Maqasid al-Shariah principles were statistically significant. The high value of $B$ indicates the most influential factor. Therefore, religiosity was the most significant factor that affects the behaviour followed by the perception towards Maqasid al-Shariah as the second factor and personal values as the third factor. This finding was consistent with past literature which found that strong religious persons can think wisely before doing something immoral. Their behaviour was guided by Islamic teachings because they know all their acts will be judged by Allah S.W.T in the hereafter. This will include their behaviour in social media. The findings were also consistent with past literature which also had arrived at the same findings (Imran et al., 2021; Ashaari et al., 2017; Shompa et al., 2019).

However, the findings also found that age factor does not affect the behaviour of the users of social media. It was not consistent with the research by Hruska and Petra (2020); Jeretta et al (2020); Hopkins and Chris (2021), in which revealed that age play important role in shaping users' behaviour.

\section{Conclusion}

The theoretical explications on religion and religiosity in Islam are numerous, but the empirical studies on the role of religion and social media behaviour is still lacking. Similarly, many scholars have discussed the principles of Maqasid al-Shariah in length but its relevancy with Muslim's behaviour has not yet been established. This may be due to lack of establish instrument to measure this concept.

In this study, the roles of religion and personal values have been studied in shaping users' behaviour while using social media. The role of religion in this paper refers to the users' level of religiosity and their perceptions towards the principles of Maqasid al-Shariah. The result in this study implies that the respondents have positive behaviour since they do not act unethically. It is also consistent with the findings in the descriptive analysis of other independent variables where the scores indicate that the respondents had positive value, high level of religiosity and have positive perceptions towards the principles of Maqasid al-Shariah. 
The findings of inferential statistics showed that religiosity, personal values and the perceptions towards Maqasid al-shariah were important to determine user's behaviour among Muslim. Most importantly, religiosity was shown to be the strongest factor. Therefore, the role of religion should be inculcated among users of social media so that they will become more concerned about their own conducts. The finding is consistent with previous studies which correlated the role of religion with individuals' behaviour irrespective whether the conduct is taken place in the physical world or in the cyberspace.

This finding acts as secondary knowledge by providing insight into applied aspects of the role of religion. Therefore, the results of the study have implications for many parties especially the authority concerned. As a policy implication, the role of religion and personal values should be given strong emphasis even in school curriculum in order to educate users to behave ethically when using social media. It is important to highlight that school children are heavy users of social media and it is our duty to inculcate good value even from small age (Hassan \& Rashid, 2012).

On a practical note, it is recommended that relevant authoritative bodies such as the Malaysian Communication and Multimedia Commission to look into adopting the concept of Maqasid al-Shariah in influencing the behaviour of social media users. Safeguarding its five pillars of religion, life, intellect, dignity and wealth will be placed as the main consideration for social media users when educating them with this concept. This would be instrumental in protecting social media users from undesirable behaviour when being online, such as invasion of privacy, online fraud, defamation, or getting involved in risky and potentially harmful activities when using social media.

In relation to this, religious institutions, whether under the government or run by the community, can play an important role in educating social media users. For Muslims, it is their given duty to spread the message of Islam, thus they must be mindful when interacting with others, including in the online environment. This will also portray Islam as a religion that gives importance to righteous behaviour in any situation. Hence, religion would become a major consideration by social media users. Therefore, the fruits of the religious education provided the religious institutions must not be merely the acquisition of knowledge but must be a way of life that begins before birth and occurs in informal or formal setting throughout one's life. It is definitely true not only to Muslims but also to other religions since all religions teach their followers not to behave unethically and cause destruction in this world.

With rapid development in technology, it is inevitable to seclude ourselves from being the users of technology and as a parent to control our children in using social media. The challenges become more critical since the social media plays an important role in shaping the personal values of younger generation and the worries are the disseminated values through these media are disruptive. It is really hope that religion should play important role as a shield to defend from negatives elements as well as a guidance to shape one's behaviour. Therefore, it is a duty of all family members in youth religiosity development.

Besides the role of religion, personal values are also important to determine one's conducts. By virtue of social media such as Facebook and Twitter, users have no limit to connect or communicate with others regardless of space and time. This easy way of interaction makes users farther away from social relationships with outside societies. Therefore, it is important 
to inculcate good value so that the users still believes that human interaction is more important as opposed to virtual relationships on social media.

A society cannot exist peacefully without citizens, either Muslim or non-Muslims, who are moral and ethical and conduct themselves accordingly. Most importantly, the backbone and the foundation of morality and ethics is religion and its tenets and values.

\section{Acknowledgment}

This research was supported by the Ministry of Higher Education Malaysia, Fundamental Research Grant Scheme (FRGS) "Formulating a new consumer protection framework for the fourth industrial revolution towards realizing society 5.0" FRGS/1/2019/SSO6/UPM/02/5.

\section{References}

Abutaleb, S., El-Bassiouny, N. M., \& Hamed, S. (2021). A conceptualization of the role of religiosity in online collaborative consumption behaviour. Journal of Islamic Marketing, 12(1), 180-198.

Abu Zahrah, M. (1997). Usul Al-Fiqh. Cairo, Egypt: Dar Al-Fikr Al-Arabi.

Ahmed, Y. A., Ahmad, M. N., Ahmad, N., \& Zakaria, N. H. (2019). Social media for knowledgesharing: a systematic literature review. Telematics and Informatics, 37, 72-112.

Al-Mashrafi, A. (2013). A master dissertation: Comparative study of unethical behaviour in computer use among Institute of Education and Kulliyyah of Information Technology students at International Islamic University Malaysia. Gombak: International Islamic University Malaysia.

Al-Zeera. (2001). Wholeness and holiness in education: An Islamic perspective. Herndon, Virginia: International Institute of Islamic Thought.

Ashaari, M. F., Yaacob, L., \& Rasit, R. M. (2017). Dinamisme Islam dan dakwah di alam siber. Bangi: Universiti Kebangsaan Malaysia Publisher.

Bandura, A. (1978). Social learning theory of aggression. Journal of Communication, 28(3), $12-$ 29.

Bandura, A. (2009). Social cognitive theory. In R. Vasta (Ed.), Annals of Child Development. Six Theories of Child development (pp.1-60). JAI Press.

Bower, G. H. (1978). Contacts of cognitive psychology with social learning theory.Cognitive Therapy and Research, 2(2), 123-146.

Cheung, M. L., Pires, G., Rosenberger III, P. J., Leung, W. K. S., \& Chang, M. K. (2021). The role of social media elements in driving co-creation and engagement. Asia Pacific Journal of Marketing and Logistics, 33 (9). https://doi.org/10.1108/APJML-03-2020-0176.

Colicev, A., Malshe, A., Pauwels, K., \& O'Connor, P. (2018). Improving consumer mindset metrics and shareholder value through social media: the different roles of owned and earned media. Journal of Marketing, 82 (1), 37-56.

Computer Ethics Institute. (1992). Ten Commandments of Computer Ethics. Available: http://computerethicsinstitute.org/publications/tencommandments.html.

Cybersecurity Malaysia. (2021). "MyCERT Incident Statistics,". Available:

https://www.cybersecurity.my/en/index.html.

Dillman, D. A. (2000). Mail and internet Surveys: The tailored design method (2nd ed.). New York: John Wiley and Sons. 
Faradillah, I. H. F. (2015). Hubungan penggunaan media sosial dan penerimaan mesej dakwah. [Conference Presentation] $2^{\text {nd }}$ Int. Conf. on Management and Muamalah, Bangi, Selangor.

Fazli, A. H., Anuar, M. M., \& Engku Ali, E. M. T. (2015). Cabaran media baru sebagai medium pengajaran agama dan penyelesaiannya dalam perspektif Islam. Jurnal Islam dan Masyarakat Kontemporori, 1, 12-23.

Hamid, S. A. (2016). Pengaruh media sosial terhadap perubahan sosial masyarakat. Journal Social Sciences and Humanities, 1, 214-226.

Hassan, J., \& Abdul Rashid, R. S. (2012). Ketagihan penggunaan internet di kalangan remaja sekolah Tingkatan 4 di Bandaraya Johor Bahru. Journal of Technical, Vocational \& Engineering Education, 6, 23-43.

Hruska, J., \& Petra, M. (2020). Use of social media platforms among adults in the united states-behaviour on social media. Societies, 10(1), 27.

Homer, P. M., \& Kahle, L. R. (1988). A structural equation test of the value-attitude behaviour hierarchy. Journal of Personality and Social Psychology, 54, 638-646.

Hopkins, J., \& Chris, H. K. T. (2021). Choosing a social media platform: genre and social ties in urban Malaysia. International Journal of Communication, 15, 1-21.

Imran, A. M., Kamal, H., \& Yousuf, M. S. (2021). Attitudinal and direct association between personal value beliefs and users' banner ad-click response on social network sites. Pakistan Social Sciences Review, 5(1), 1127-1141.

Institute for Community and Peace Studies. (2006). Muslim religiosity and personality indexing: implications for nation building. Serdang: Institute for Community and Peace Studies.

Jeretta, H. N., Susana, J. E., Joanna, P., \& Magdalena, M. S.(2020). Do technology and social media preferences differ with age? A study of the use of social technologies for business purposes in Spain. Journal of Computer Information Systems, 60(2), 101-112

Justin, T., Aamna, A. S., \& lan, G. (2019). The sacred and the profane: social media and temporal patterns of religiosity in the United Arab Emirates. Journal of Contemporary Religion, 34(3), 489-508.

Kahle, L. R., \& Kennedy, P. (1988). Using the List Of Values (LOV) to understand consumers. Journal Services Marketing, 2(4), 49-56.

Khazanch, D. (1995). "Unethical behaviour in information systems: The gender factor. Journal of Business Ethics, 14(9), 741-749.

McQuail, D. (1994). The rise of media of mass communication. London: Sage.

McGregor, S. L. T. (2000). Using social and consumer values to predict market-place behaviour: Questions of congruency. Journal of Consumer Studies and Home Economics, 24(2), 94103

Najmul Islam, A. K. M., Laato, S., Talukder, S., \& Sutinen, E. (2020). Misinformation sharing and social media fatigue during COVID-19: An affordance and cognitive load perspective. Technological Forecasting and Social Change, 159, 120.

Nurazlina, D., Elistina, A. B., \& Aini, M. S. (2015). Consumer legal literacy, values and consumerism practices among members of Consumer Association in Malaysia. Asian Social Science, 11(12), 189-1999.

Piaget, J. (1964). Cognitive development in children: Piaget development and learning. Journal of Reseach in Science Teaching, 2, 176-186. 
Ping Chiang, I., Wong, R., \& Huang, C. H. (2019). Exploring the benefits of social media marketing for brands and communities. International Journal of Electronic Commerce Studies, 10 (2), 113-140.

Pitts, R. E., \& Woodside. (1983). Personal value influences on consumer product class and brand preferences. Journal of Social Psychology, 58, 193-198.

Saodah, W., Arabi, S. I., \& Norealyn, M. (2012). Social media use for information-sharing activities among youth in Malaysia. Journalism and Mass Communication, 2(11), 10291047.

Schwartz, S. H. (1994). Are there universal aspects in the content and structure of values? Journal Social Issues, 50(4), 19-45.

Shompa, Z. A., Saidin, A. Z., Hussin, H., Muhammad, M. R., \& Abu Bakar, E. (2019). A descriptive analysis of values and Maqasid al-Shariah in social media use among students of IIUM. Journal of Information Systems and Digital Technologies, 1(1), 1-16.

Siddiqui, S., \& Singh, T. (2016). Social media its impact with positive and negative aspects. International Journal of Computer Applications Technology and Research, 5(2), 71-75. 